\title{
The Evidence of Coastline Changes in Banten Bay, Indonesia
}

\author{
Ahmad Bayhaqi ${ }^{1{ }^{* *}, \text { Ulung Jantama Wisha }}{ }^{2}$ and Marindah Yulia Iswari ${ }^{1}$ \\ ${ }^{1}$ Research Center for Oceanography, Indonesian Institute of Sciences, Jakarta 14430, Indonesia \\ ${ }^{2}$ Research Institute for Coastal Resources and Vulnerability, Ministry of Marine Affairs and Fisheries, \\ Padang 25245, Indonesia
}

('Corresponding author's e-mail: ahmad.bayhaqi@lipi.go.id)

Received: 15 September 2020, Revised: 21 May 2021, Accepted: 31 May 2021

\begin{abstract}
Consisting of semi-circular body, coastal region in the Banten Bay holds a significant role for both marine ecosystem and human activities. The change of its coastline due to the erosion/sedimentation process may affect the ecosystem and economic purposes. This study aims to figure out the evidence of coastline changes in Banten Bay using remote sensing and numerical model. The recording satellite data from Landsat 5 TM, Landsat 7 ETM+ and Landsat 8 OLI during 1990 - 2019, are employed to examine the coastline changes using Normalized Different Water Index (NDWI). Besides, applying the Langevin equation in the particle tracking model, the sediment data from observation in April 2016 are utilized to simulate the trajectory of sediment movements to understand the hydrodynamic processes which cause the changes of coastline. Over 30 years, satellite imageries showed the significant changes with the average of 0.8 (sedimentation) and -0.5 (erosion) $\mathrm{km}$ for the western and eastern part respectively. The simulation of sediment movements illustrates the dominant westward direction with the maximum 247.88 $\mathrm{m}^{3} /$ day supporting the sedimentation in the western part. Moreover, the distribution of suspended sediment demonstrates the highest concentration in the eastern part with the range $9.47-249.54 \mathrm{mg} / \mathrm{L}$ indicating the evidence of intense erosion in the eastern part.
\end{abstract}

Keywords: Coastline changes, Satellite, Sediment movements, Banten Bay

\section{Introduction}

The coastal region is a meeting point between land and the ocean, this site is the most dynamic regions on the earth's surface [1]. This area is extremely critical for several activities such as fisheries, agriculture and economic purposes including tourism and recreation where those activities may affect the changes of coastline [2]. The changes of coastline can be initiated by the processes which come from the land as well as from the ocean [3] and can also affect the local community. Then, the study of coastline changes is very essential since it may well be impacted as well as feedback on both land and ocean processes influencing coastal activities.

Banten Bay is located on Banten Province, the northwestern tip of Java Island. Consisting of a semicircular body of water and as an example of a shallow-water reef environment, this site has a lot of marine potentials [4] including a rich seagrass ecosystem [5], coral reef communities with $2.5 \mathrm{~km} 2$ areas, a number of small-scale rivers, canals from shrimp ponds and more than 10 islands. On the other hand, based on the geographical condition, Banten Bay is full of maritime activities acting as the shipping route to bridge 2 big islands, Java and Sumatera [6]. Moreover, a massive development from oil and gas refinery, industries, and manufacturers, enhances the industrial activities in the neighboring site which may potentially impact the marine environment and water quality [7]. Related to the natural processes, the hydrodynamic in Banten Bay is mostly influenced by ocean-atmosphere interactions in the Java Sea in which the previous study has been suggested that the dynamic of hydrodynamic processes in Banten relating to the monsoonal season will potentially induce the accretion and abrasion along the Banten Bay coastal region [8].

To investigate the changes in the coastline, a large and long-time series data set which require a high budget are needed. As an alternative way, several studies have been reported on using satellite data [9-12] to analyze the coastal changes in several Indonesian coastal areas. A satellite remote sensing is recognized as an effective instrument to detect the coastline changes in a fast way without considering the 
high cost [13]. On the other hand, a numerical model also can be an alternative method to investigate the coastline changes [14]. The coastline changes in Banten Bay have been studied by [3]. However, it only based on a remote sensing study. Then, this study is not only providing valid evidence of coastline changes in Banten Bay using remote sensing but also highlighting its sediment transport as revealed from the model simulation. The information is highly essential for the local government in making the coastal zone management policy

\section{Materials and methods}

The observation was conducted in April 2016 to obtain the sediment sample in Banten Bay. The data were taken from 16 sampling stations using the sediment grab, in which later were analyzed by granulometry. The grid point of stations was distributed in whole bay to get the information of spatial sediment characteristic pattern (Figure 1). The information of grain size was used as the input data for the model simulation. Furthermore, the Total Suspended Sediment (TSS) data were obtained from Research Institute for Coastal Resources and Vulnerability, Ministry of Marine and Fisheries Affairs of Indonesia (KKP). The TSS data were employed to validate the TSS model that will show the turbulence events within Banten Bay during flood and ebb tides.

Besides, to investigate the coastline changes, we used the following different satellite imageries such as Landsat 5 TM, Landsat 7 ETM+ and Landsat 8 OLI with the recording years: 1990, 1995, 1999, 2003, 2007, 2010, 2013, 2016 and 2019 (List of data can be seen in Table 1). The time series of satellite data are not in the same interval due to the cloud cover and damage in Scan Line Corrector (SLC). At the first step, the satellite data were validated by the radiometric correction. Then, they were cropped to obtain the exact location which matched the study region. Furthermore, to get the coastline imageries, we used the Normalize Difference Water Index (NDWI) [15] to differentiate land and water. This method consists of 2 channels, namely green and infrared channel. These channels work differently to the reflection in the water. The green channel optimizes the reflection, while the infrared channel minimizes the reflection. The NDWI process produces a value between 1 and -1 where the higher values indicate more water composition.

Table 1 List of LANDSAT imageries.

\begin{tabular}{cccc}
\hline No. & Image & Landsat & Year \\
\hline 1 & LT05_L1TP_123064_19900716_20170129 & Landsat 5 TM & 1990 \\
2 & LT05_L1TP_123064_19950527_20170109 & Landsat 5 TM & 1995 \\
3 & LT05_L1TP_123064_19990709_20161217 & Landsat 5 TM & 1999 \\
4 & LE07_L1TP_123064_20030407_20170126 & Landsat 7 ETM+ & 2003 \\
5 & LT05_L1TP_123064_20070901_20161113 & Landsat 5 TM & 2007 \\
6 & LT05_L1TP_123064_20100520_20161015 & Landsat 5 TM & 2010 \\
7 & LC08_L1TP_123064_20130816_20170503 & Landsat 8 OLI & 2013 \\
8 & LC08_L1TP_123064_20160418_20170326 & Landsat 8 OLI & 2016 \\
9 & LC08_L1TP_123064_20190105_20190130 & Landsat 8 OLI & 2019 \\
\hline
\end{tabular}

Coastline changes are closely related to sediment dynamics. Then, the model simulation performed using MIKE 21 modeling software was employed to investigate the distribution of sediment movements using the particle tracking model (PTM). Before simulating the PTM, we simulated beforehand the hydrodynamic module (HD) within the flow model FM modeling system with triangular flexible mesh element. The flow model was based on the 3D incompressible Reynold averaging Navier-Stokes equations, consisting of continuity and momentum for $x$ and $y$ components [16] as follows:

$$
\begin{aligned}
& \frac{\partial h}{\partial t}+\frac{\partial h \underline{u}}{\partial x}+\frac{\partial h \underline{v}}{\partial y}= \\
& \begin{aligned}
\frac{\partial h \underline{u}}{\partial t}+\frac{\partial h \underline{u}^{2}}{\partial x}+\frac{\partial h \underline{v u}}{\partial y} & \\
& =f \underline{v} h-g h \frac{\partial \eta}{\partial x}-\frac{h}{\rho_{o}} \frac{\partial P_{a}}{\partial x}-\frac{g h^{2}}{2 \rho_{o}} \frac{\partial \rho}{\partial x}+\frac{\tau_{s x}}{\rho_{o}}-\frac{\tau_{b x}}{\rho_{o}}-\frac{1}{\rho_{o}}\left(\frac{\partial s_{x x}}{\partial x}+\frac{\partial s_{y y}}{\partial y}\right)+\frac{\partial}{\partial x}\left(h T_{x x}\right)+\frac{\partial}{\partial y}\left(h T_{x y}\right) \\
& +h u_{s} S
\end{aligned}
\end{aligned}
$$




$$
\begin{aligned}
\frac{\partial h \underline{v}}{\partial t}+\frac{\partial h \underline{u v}}{\partial x}+\frac{\partial h \underline{v}^{2}}{\partial y} & \\
& =-f \underline{u} h-g h \frac{\partial \eta}{\partial y}-\frac{h}{\rho_{o}} \frac{\partial P_{a}}{\partial y}-\frac{g h^{2}}{2 \rho_{o}} \frac{\partial \rho}{\partial y}+\frac{\tau_{s y}}{\rho_{o}}-\frac{\tau_{b y}}{\rho_{o}}-\frac{1}{\rho_{o}}\left(\frac{\partial s_{y x}}{\partial x}+\frac{\partial s_{y y}}{\partial y}\right)+\frac{\partial}{\partial x}\left(h T_{x y}\right) \\
& +\frac{\partial}{\partial y}\left(h T_{y y}\right)+h v_{s} S
\end{aligned}
$$

Where:

$t \quad=$ time

$x, y=$ Cartesian co-coordinates

$\eta \quad=$ surface elevation

$h \quad=$ total water depth

$f \quad=$ Coriolis parameter $=2 \Omega \sin \varphi$

$g \quad=$ gravitational acceleration

$\rho \quad=$ water density

$S \quad=$ component of the radiation stress tensor

$P_{a} \quad=$ atmospheric pressure

$\rho_{o} \quad=$ reference of water density

$S \quad=$ magnitude of the discharge in the point of sources

$\underline{u}, \underline{v}=$ depth-averaged velocity

$u_{s}, v_{s}=$ velocity in the ambient water

$T \quad=$ lateral stress (viscous friction, turbulent friction, and differential advection)

PTM is a model from Lagrangian discrete parcels method neglecting the interaction between propagated particles [17]. This technique portrays transport and dispersion of sediment, considering the Langevin equation which aims to formularize the motion dynamics in the form of a following stochastic differential equation $[18,19]$;

$d X_{t}=a\left(t, X_{t}\right) d t+b\left(t, X_{t}\right) \xi_{t} d t$

where:

$$
\begin{aligned}
& a=\text { Drift term } \\
& b=\text { Diffusion term } \\
& \xi=\text { Random number }
\end{aligned}
$$

To simulate a trajectory, the Euler approximation $Y$ for a given time discrete is frugally started from the initial condition $Y_{o}=X_{o}$ which then reiterates to gain the next results.

$Y_{n+1}=Y_{n}+a\left(t, X_{t}\right) Y_{n} \Delta_{n}+b\left(t, X_{t}\right) Y_{n} \Delta W_{n}$

$\Delta W_{n}=W_{t}-W_{s} \in N\left(\mu=0, \sigma^{2}=\Delta_{n}\right)$

where:

$n=1,2,3 \ldots$ according to the Euler scheme with drift $a$ and diffusion coefficient $b$

$\Delta W_{n}=$ the normal distribution of Gaussian increment of the Wiener process $W$

$W=$ continuous-time Gaussian stochastic process with independent increments over the subinterval $\tau_{n} \leq t \leq \tau_{n+1}$

Beside the sediment data, the several inputs for model simulation in this study cover 1) bathymetry from Indonesian Navy (Pushidrosal) and Spatial Information Agency of Indonesia (BIG), 2) tidal prediction and 3) hourly wind data from Meteorological, Climatological and Geophysical Agency of Indonesia (BMKG). The simulation also considers the biggest rivers in the Banten Bay as the source of sediment intake. Moreover, to figure out the sediment movement pattern seasonally, the model was simulated following the monsoonal cycle (the dominant seasonal cycle in Indonesian waters).

After the PTM was simulated, we reiterated the model applying the Mud Transport (MT) model to figure the suspended sediment out. In this stage, a Spectral Wave module (SW) was run beforehand, and the results of HD and SW model were reapplied to run the MT module. HD and MT modules were run at 
the same time and resulted current patterns and sediment transport within the water column [20], The overall set-up for model simulation is shown in Table 2.

In addition to SW model, the simulation was reiterated for several years applying secondary wind data. The results together with the existing sediment data were used to estimate the sediment transport in Banten Bay which was investigated by employing the correlation between sediment transport and waves energy flux component in the form of flux equation [21] as follow:

$P_{1}=\frac{\rho g}{8} H_{b}^{2} C_{b} \sin \alpha_{b} \cos \alpha_{b}$

where:

$P_{1}=$ wave energy flux component along the coast at the time of breaking $(\mathrm{kg} \cdot \mathrm{m} /$ day $)$

$\rho=$ specific gravity of sea water $\left(\mathrm{kg} / \mathrm{m}^{3}\right)$

$g=$ acceleration of gravity $=9.81\left(\mathrm{~m} / \mathrm{s}^{2}\right)$

$H_{b}=$ breaking wave height $(\mathrm{m})$

$C_{b}=$ breaking wave celerity $(\mathrm{m} / \mathrm{s})$

$\alpha_{b}=$ breaking wave angle

Then total sediment transport can be calculated using the following formula:

$Q_{s}=\frac{K}{\left(\rho_{s}-\rho\right) g(1-n)} P_{1}$

where:

$Q_{s}=$ sediment transport along the coast $\left(\mathrm{m}^{3} / \mathrm{s}\right)$

$K=$ Given by [20], $\mathrm{K}=0.39$, in which the formula above used significant wave height value

$\rho_{s}=$ Specific gravity of sand $\left(\mathrm{kg} / \mathrm{m}^{3}\right)$

$n=$ Porosity $(\mathrm{n} \sim 0.4)$

Suspended sediment model is also simulated considering a bed and suspended loads [22]. The applied model calculates the sediment load separately. It is then summed to obtain the total load based on the sediment load concentration as follow:

$\frac{\partial C_{i}}{\partial t}+\frac{\partial u C_{i}}{\partial x}+\frac{\partial v C_{i}}{\partial y}+\frac{\partial\left(w-w_{i}\right) C_{i}}{\partial z}=\frac{\partial\left(A_{u} \frac{\partial C_{i}}{\partial x}\right)}{\partial x}+\frac{\partial\left(A_{u} \frac{\partial C_{i}}{\partial y}\right)}{\partial y}+\frac{\partial\left(K_{h} \frac{\partial C_{i}}{\partial x}\right)}{\partial z}$

where:

$C_{i}=$ Concentration value of suspended sediment

$A_{u}=$ Horizontal Eddy viscosity

$K_{h}=$ Vertical Eddy viscosity

$w-w_{i}=$ Settling velocity adjusted with sediment type applied in the model

In the surface layer, the value of flux boundary condition used $K_{h} \frac{\partial C_{i}}{\partial x}=0, z=\zeta$, for bed layer, the sediment flux has a different deposition and turbulence levels. For deposited sediment, we used the value of $K_{h} \frac{\partial c_{i}}{\partial x}=E_{i}-D_{i}, z=\zeta$, and for the stirred particle, we used the formula of $E_{i}=\Delta t Q_{i}(1-$ $\left.P_{b}\right) F_{b i}\left(\frac{\tau_{b}}{\tau_{c i}}-1\right)$, which $Q_{i}$ is the erosion flux, $P_{b}$ is porosity in the bottom waters, $F_{b i}$ is the fraction of bottom sediment, $\tau_{b}$ is the bottom shear stress pressure, and $\tau_{c i}$ is the critical shear stress of sediment. 


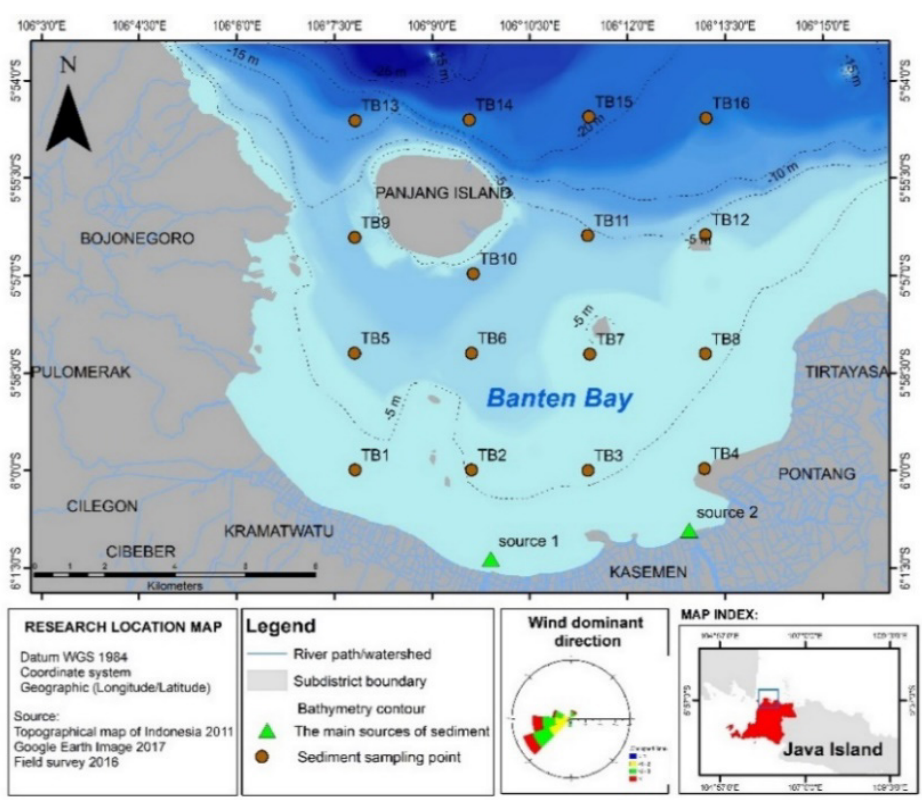

Figure 1 Stations of sediment sampling: The green triangle indicates the source of sediment input which is applied in the particle tracking model.

Table 2 Model set-up applied in the simulation.

\begin{tabular}{|c|c|}
\hline Parameter & Applied in the simulation \\
\hline \multicolumn{2}{|l|}{ HD module } \\
\hline Mesh elements & $\begin{array}{l}\text { Element mesh area }=22,200 \mathrm{~m}^{2} \\
\text { Minimal angle of element mesh }=26 \\
\text { Maximum nodes }=100,000 \\
\text { Bathymetry = Indonesian Navy bathymetry map digitation }\end{array}$ \\
\hline Simulation Period & $\begin{array}{l}\text { Number of time step }=1051200 \\
\text { Time step interval }=30 \mathrm{~s} \\
\text { Simulation start date }=01 / 01 / 2016 \\
\text { Simulation end date }=31 / 12 / 2016\end{array}$ \\
\hline Flood and Dry & $\begin{array}{l}\text { Drying depth }=0.005 \mathrm{~m} \\
\text { Flooding depth }=0.05 \mathrm{~m} \\
\text { Wetting depth }=0.1 \mathrm{~m}\end{array}$ \\
\hline Bed resistance & Manning number $=28 \mathrm{~m}^{1 / 3}$ \\
\hline Boundary condition & Tidal predictions in every open boundary \\
\hline \multicolumn{2}{|l|}{ SW module } \\
\hline Wind forcing & $\begin{array}{l}\text { Varying in time, constant in domain } \\
\text { Wind data source: daily BMKG wind data }\end{array}$ \\
\hline \multicolumn{2}{|l|}{ MT module } \\
\hline Parameter Selection & $\begin{array}{l}\text { Number of fractions }=1 \\
\text { Number of layers }=1\end{array}$ \\
\hline Water column parameter & $\begin{array}{l}\text { Fraction 1: } \\
\text { Settling velocity coefficient }=0.25 \mathrm{~m} / \mathrm{s} \\
\text { Critical shear stress }=0.2 \mathrm{~N} / \mathrm{m}^{2}\end{array}$ \\
\hline Bed parameter & $\begin{array}{l}\text { Layer } 1 \\
\text { Erosion description }=\text { Hard mud } \\
\text { Erosion coefficient }=5.10-5 \mathrm{~kg} / \mathrm{m}^{2} / \mathrm{s} \text { (constant) } \\
\text { Critical shear stress }=0.2 \mathrm{~N} / \mathrm{m}^{2}(\text { constant }) \\
\text { Power of erosion }=1 \\
\text { Density of bed layer }=400 \mathrm{~kg} / \mathrm{m}^{3} \text { (constant) } \\
\text { Bed roughness }=0.001 \mathrm{~m} \text { (constant) }\end{array}$ \\
\hline
\end{tabular}




\begin{tabular}{ll}
\hline Parameter & Applied in the simulation \\
\hline Forcing & Reapplied from HD and SW modules \\
\hline Initial condition & $\begin{array}{l}\text { Fraction concentration }=0 \mathrm{~kg} / \mathrm{m} 3 \\
\text { Layer thickness }=1 \mathrm{~m} \text { outside the bay and } 0 \mathrm{~m} \text { for open ocean } \\
\text { Fraction distribution }=100\end{array}$ \\
\hline PT module & \\
\hline Classes & Sediment \\
& Minimum mass $=0.1 \mathrm{~kg}$ \\
\hline Sources & Fraction flux \\
& Northeast monsoon \\
& Karangantu Estuary $=0.16 \mathrm{~kg} / \mathrm{m}^{3}$ \\
& Cibanten Estuary $=0.16 \mathrm{~kg} / \mathrm{m}^{3}$ \\
& Southwest monsoon \\
& Karangantu Estuary $=0.1 \mathrm{~kg} / \mathrm{m}^{3}$ \\
& Cibanten Estuary $=0.1 \mathrm{~kg} / \mathrm{m}^{3}$ \\
\hline Decay & Decay rate $=0.0001 / \mathrm{s}$ \\
\hline Settling & Settling velocity $=0.001 \mathrm{~m} / \mathrm{s}$ \\
\hline Erosion & Critical shear stress $=0.2 \mathrm{~N} / \mathrm{m}^{2}$ \\
\hline &
\end{tabular}

\section{Results and discussion}

Overall, the results showed that there are significant changes in the coastline of Banten Bay (Figure 2). The latest year (2019) is symbolized as a red line, while a black one illustrates the earliest year (1990). Looking at the detail, the coastline in the middle of Bay has not been a siginificant change. However, the extreme sedimentation has been occured in the western side of Bay. On the other hand, the intense erosion has been observed in the eastern part of the Bay. Simple calculation was applied by considering the difference distance from the initial year and latest condition. As a result, the mean of coastline change in western part is $0.8 \mathrm{~km}$ and the eastern part is $-0.5 \mathrm{~km}$. The minus value indicates the decrease of coastline (erosion), while the plus sign shows the increase of coastline (sedimentation).

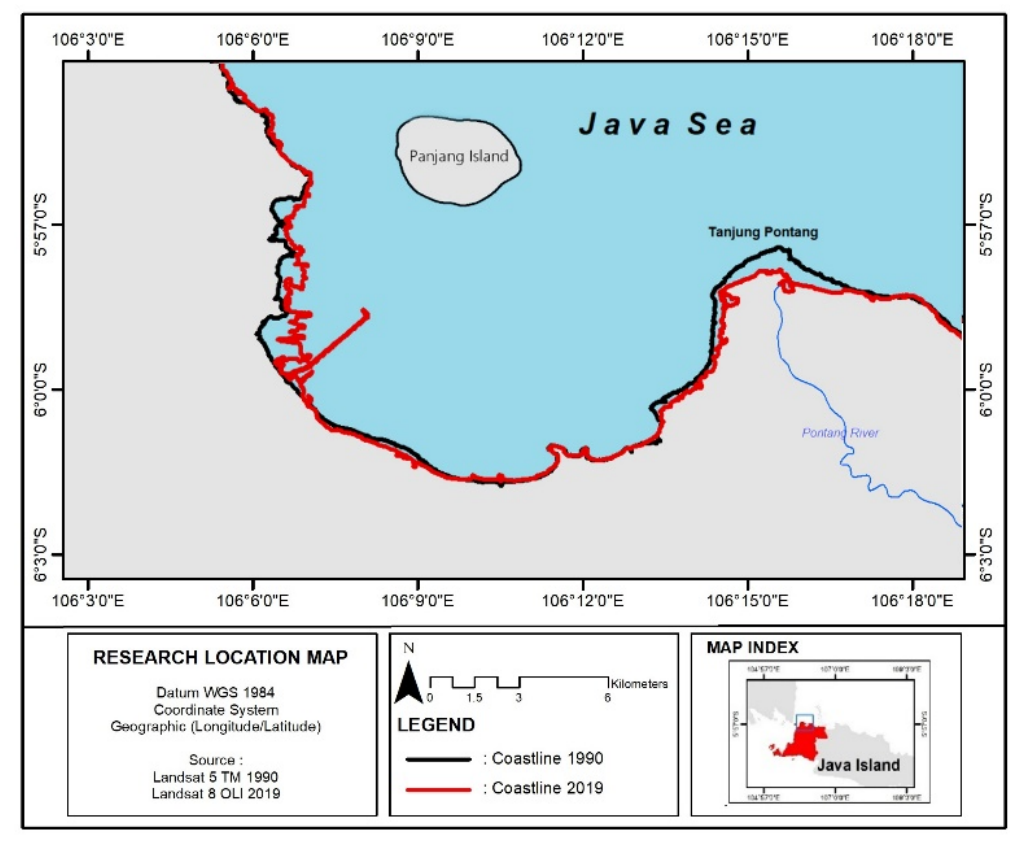

Figure 2 Coastline changes in Banten Bay during 1990 - 2019 using remote sensing data. 
Furthermore, based on imagery composite from Landsat 5 TM 457 and Landsat 8 OLI 567 (Figure 3), the coastline changes in the western part of Banten Bay during the study period are most influenced by the increasing of development. In 1990, the western coast was more dominated by the orange color. It means that the area was still consisting of vegetation at that time (Figure 3A1). However, the color has been changed to Cyan which interprets the massive development such as industry and port for 20 years (Figure 3A2).
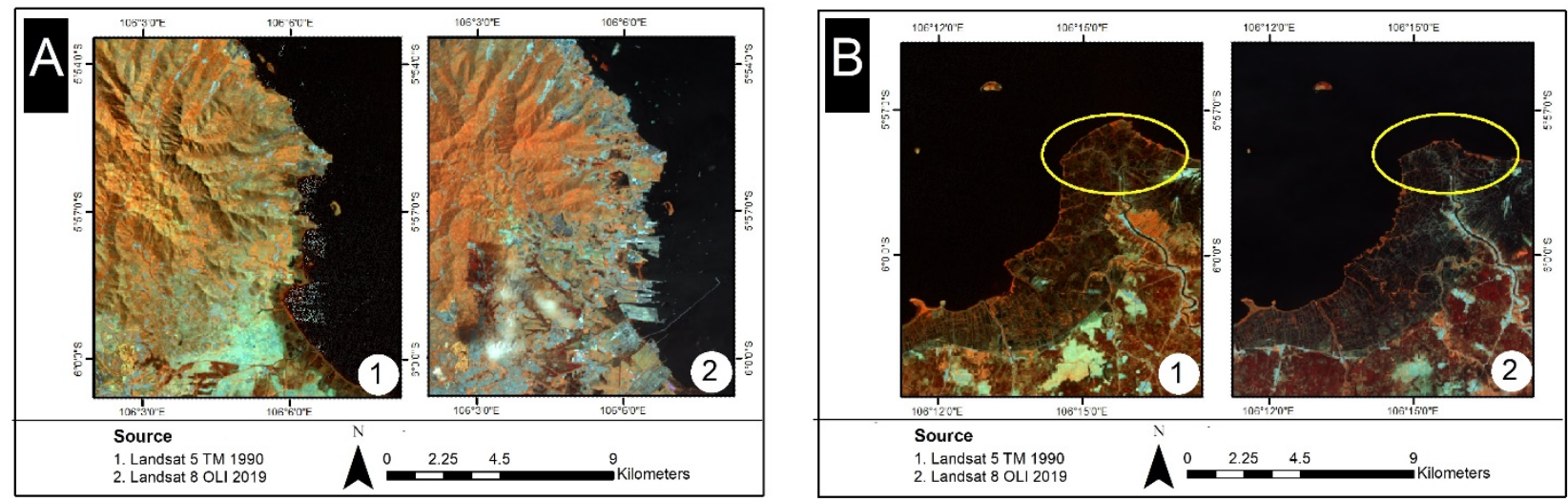

Figure 3 Coastline changes in Banten Bay during 1990 - 2019 using imagery composite from Landsat 5 TM 457 and Landsat 8 OLI 567. (A) Western part, (B) Eastern part of Banten Bay. Number 1 in the figure shows the earliest year (1990) and number 2 indicates the latest year (2019)

Remote sensing image data from 1990 - 2019 (Figures 2 and 3B) showed an intense erosion phenomenon in the eastern part (Tanjung Pontang). This result is in line with the previous research which found that Tanjung Pontang has been eroded with the $3 \mathrm{~km}$ of coastline during 1995 - 2001. Historically, there was a major river in Banten Province, namely Ciujung River. The river waters flow into Tanjung Pontang. However, since the $19^{\text {th }}$ century, the river moved to the Tengkurang Village [23-25]. Then, the potential driver for erosion in the eastern part is the ocean dynamic such as ocean current and wave. The erosion occurs when the sediment supply from the land is lower than the ocean dynamic activity. Furthermore, other potential driver is the human activities which utilize and extract sand in that region.

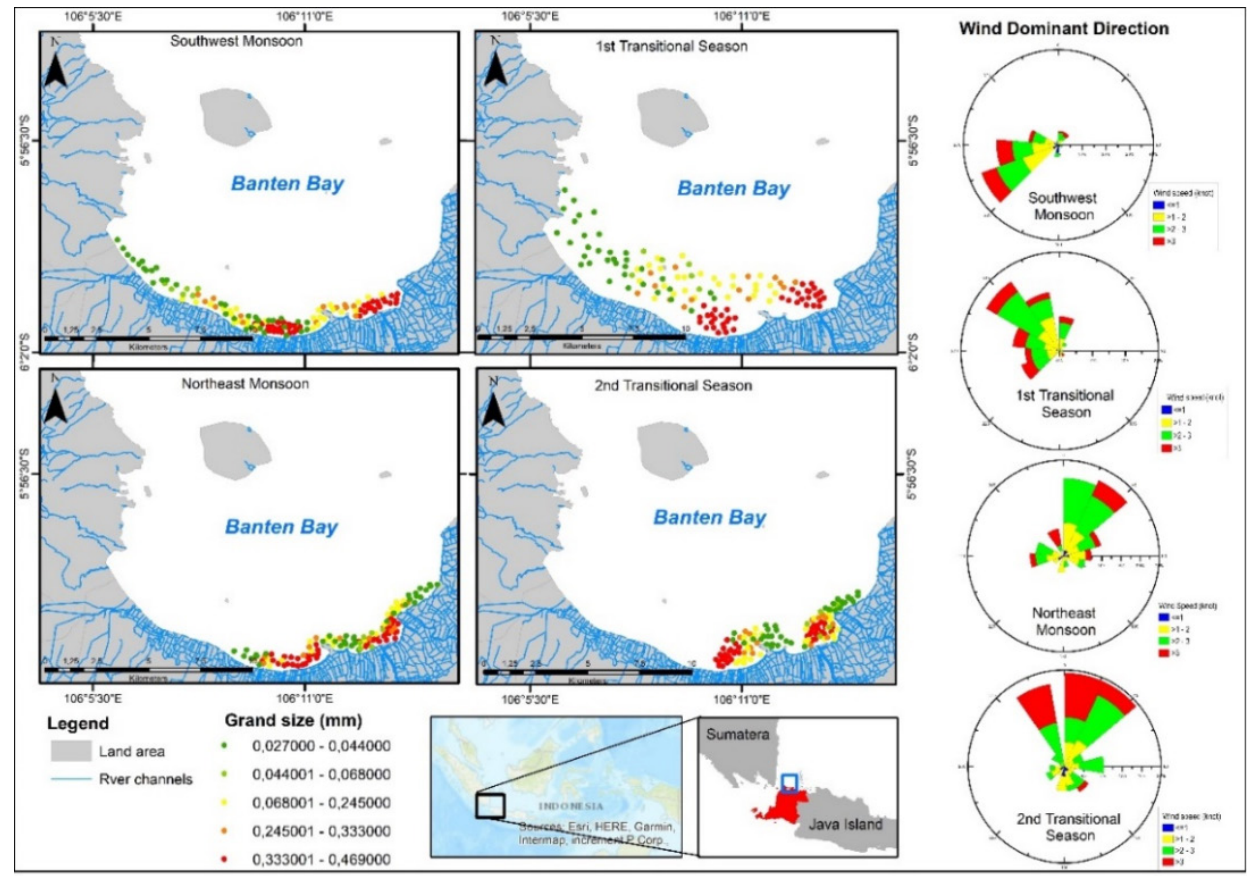

Figure 4 Seasonal sediment trajectory from the 2 sources within the bay simulated by the particle tracking model. 
Neglecting the human factor, here we present the result of the seasonal trace of sediment particle according to their grain size. The distribution of sediment in this simulation is based on wind-induced wave (1 - $3 \mathrm{kn})$. The wave can trigger the scouring and turbulence during its shore-ward propagation [26]. During the southwest monsoon, following the dominant southwest-westward wind, the sediment distribution moves to the west part of the Bay. Furthermore, as the season enters first transitional monsoon, the sediment particles move northward toward the northwestern part of the Bay. The pattern is relatively scattered. During these 2 seasons, the greatest sediment transport occurred. It potentially triggers the erosion in the eastern part and accumulation (sedimentation) in the western part. Moreover, previous research also reported that the current in the eastern part of Banten Bay is relative strong [27]. Thus, the particles with the size of $<0.068 \mathrm{~mm}$ (green dots) are easily transported by a longshore current, while the more weight particles $(0.068-0.47 \mathrm{~mm})$ tend to be settled near the sources (red dots).

Conversely, the low sediment transport rate occurs during the northeast and $2^{\text {nd }}$ transitional season. The sediment particles equally move toward the right and left. The weaker the wind-induced wave, the higher the accumulation of sediment will be yielded [28]. During northeast monsoon, the wind blows northeast-northward with low wind energy transfer on the surface. Furthermore, during the $2^{\text {nd }}$ transitional season, the wind speed begins to enhance with the low intensity, so that the sediment movement is low. The particle movement is just spinning around the sources.

Consistent with the model simulation result, Figure 5 shows the seasonal average of transport sediment occurred in the Banten Bay during 1990, 2000, 2010 and 2019, revealing the high sediment distribution is identified in southwest monsoon (DJF: December, January, and February) and the $1^{\text {st }}$ transitional season (MAM: March, April, and May). Meanwhile, during the northeast monsoon (JJA: June, July and August) and the $2^{\text {nd }}$ transitional season (SON: September, October and November), the sediment transport tends to be lower.

Based on the grain size analysis, the dominant sediment type of Banten Bay is clayey silt. The classification of sediment type based on their composition can be seen in Table 3. The sediments mainly consist of silt $(53.25 \%)$, clay $(26.19 \%)$ and sand $(18.38 \%)$. The minor composition are gravel and pebble with the percentage of $1.32 \%$ and $0.86 \%$ respectively. As the consequences, the sediment movement will be frequently evoked by currents which potentially erode the coast. Furthermore, as mentioned above, erosion in the eastern part is strongly caused by not only strong currents but also from the anthropogenic activities such as sand mining [29].

Sediment transport along the coast within Banten Bay is extremely identified in 2010 (grey histogram). This may be affected by the sand mining activities in the northern Banten Bay from 2003 until 2013. The transported sediment ranged from $198.5-624.8 \mathrm{~m}^{3} /$ day while the lowest transport occurred in 1990 (blue histogram) with the range from $24.3-455.2 \mathrm{~m}^{3} /$ day.

Table 3 Grain size analysis result.

\begin{tabular}{cccccccc}
\hline No & Statistic Description & Gravel (\%) & Pebble (\%) & Sand (\%) & Silt (\%) & Clay (\%) & Type \\
\hline 1 & Mean & 1.32 & 0.86 & 18.38 & 53.25 & 26.19 & Clayey Silt \\
2 & Max & 7.94 & 4.25 & 82.50 & 77.38 & 68.42 & \\
3 & Min & 0 & 0 & 0.52 & 9.41 & 7.20 & \\
4 & Standard dev & 2.67 & 1.27 & 24.59 & 19.57 & 14.19 & \\
\hline
\end{tabular}

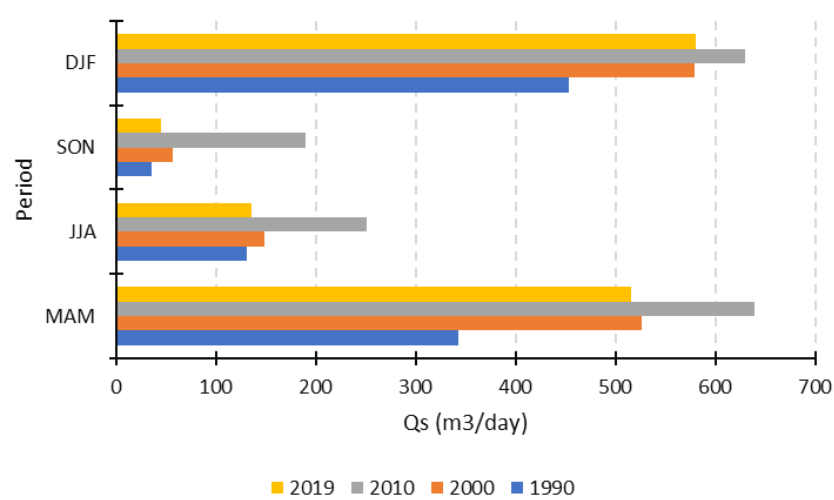

Figure 5 Seasonal variability of sediment transport along the coast every ten years from 1990 to 2019 within the Banten Bay. 
Related to the mean of monthly sediment transport within the bay (Figure 6). The negative values represent the westward particle transport, while the positive values show the eastward transport. Then the 0 point for this term is the initial point of sediment source in the model simulation. The significant transport is identified in December reaching $247.88 \mathrm{~m}^{3} /$ day and the lowest value is $87.86 \mathrm{~m}^{3} /$ day occurred in April. Overall, the westward sediment transport has higher value with $859.29 \mathrm{~m}^{3} /$ day than the eastward transport $\left(843.28 \mathrm{~m}^{3} /\right.$ day). Thus, the high potential of accretion occurrence would be in the western part. However, without the huge difference, sediment transport value tends to be equal between westward and eastward. That condition means other factors such as development and coastal building also contribute to the unstable sediment transport along the coast [30]. Furthermore, the intense turbulence and resuspension of sediment during the high tidal condition also should be considered [31].

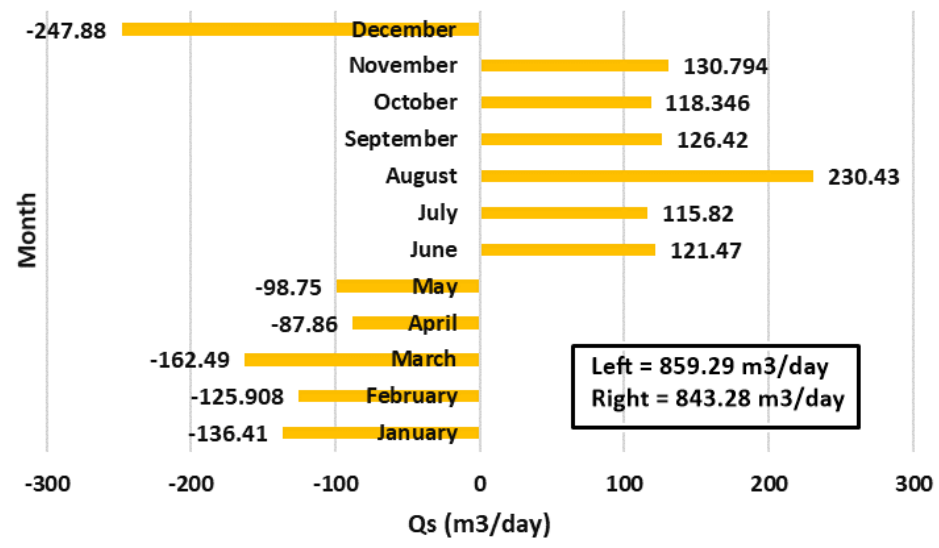

Figure 6 Monthly average of sediment transport at the sources of simulation.

As the other approach, we also provide the distribution of Total Suspended Sediment (TSS) during the high tide and low tide condition (Figure 7) with the error value of $9.87 \%$. During both conditions, the highest concentration of TSS is observed in the eastern part of Bay. Taking a note, the TSS value indicates the sediment type that cannot be easily accumulated due to its small size [32-33]. In addition, with the additional forcing from the strong current, the erosion phenomenon has been occurred in the eastern part of the Bay. The highest value of TSS is $249.54 \mathrm{mg} / \mathrm{L}$ during the high tide, while the lowest value occurred when the low tide with the $9.47 \mathrm{mg} / \mathrm{L}$.
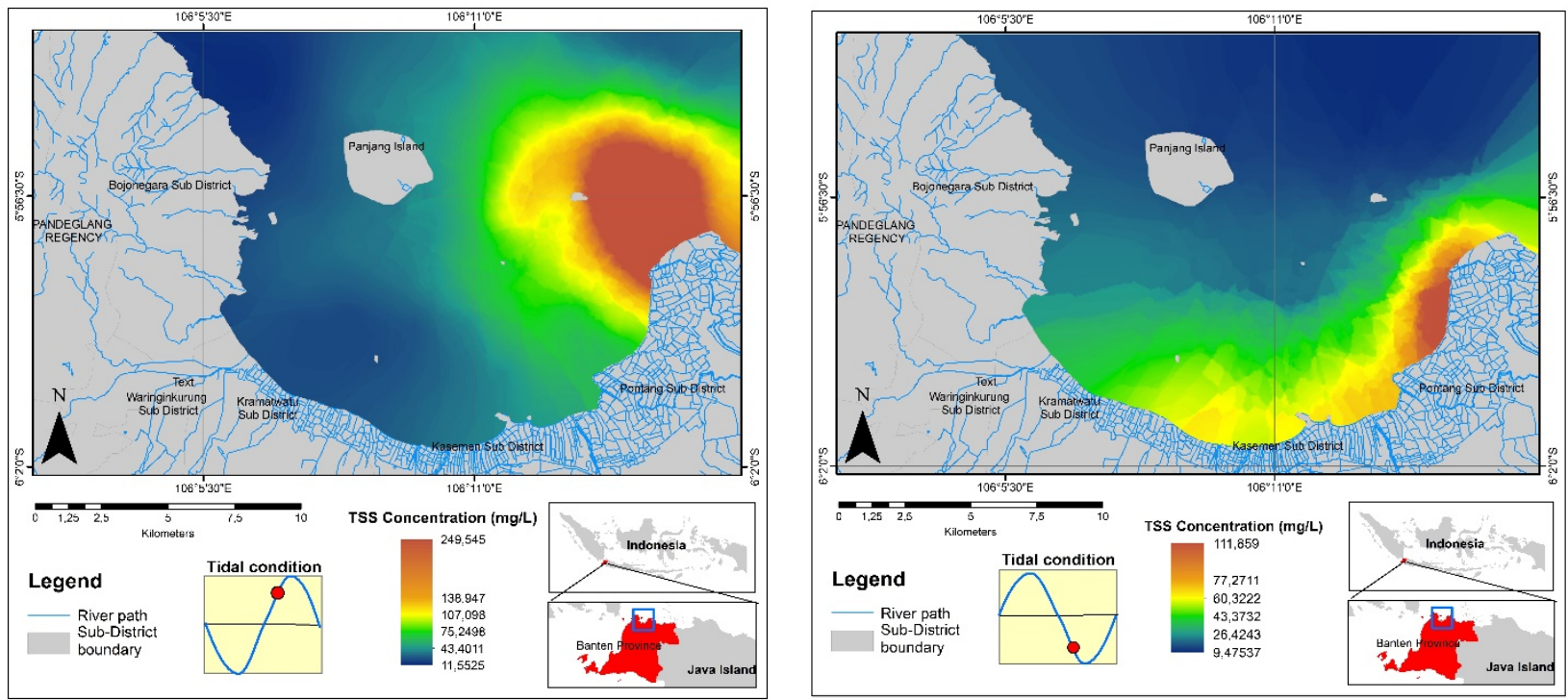

Figure 7 Spatial TSS distribution based on model simulation during high tide (left pane) and low tide (right panel). 


\section{Conclusions}

Several evidence for the coastline changes in Banten Bay has been presented from the satellite imageries and model simulation. Over the periods, satellite imageries showed the significant changes in the western and eastern part of Bay. Model simulation which produces the sediment particle movement and TSS spatial distribution has been provided the big picture of the potential driver for coastline changes. Consisting of TSS high concentration, the strong current in the eastern part can easily move the sediment toward the western part. This condition leads to the erosion in the eastern part and sedimentation in the western part. This study opens the further task about the contribution from the other factors which are not included in this paper such as tidal correction for the satellite imageries and anthropogenic activities.

\section{Acknowledgements}

The observation of this study is funded by DIPA-LIPI financial year 2016 as a part of project about Sediment Quality in Banten Bay. The authors would like to show a gratitude to Dr. Dwi Hindarti as coordinator of the project.

\section{References}

[1] MD Harley, IL Turner, AD Short and R Ranasinghe. A reevaluation of coastal embayment rotation: The dominance of cross-shore versus alongshore sediment transport processes, Collaroy-Narrabeen Beach, Southeast Australia. J. Geophys. Res. 2011; 116, F04033.

[2] MI Hassan and NH Rahmat. The effect of coastline changes to local community's social-economic. In: Proceedings of International Conference on Geomatic and Geospatial Technology (GGT), Kuala Lumpur, Malaysia. 2016, p. 25-36.

[3] G Aliyuddin and A Damayanti. Coastline changes in Serang City, Banten Province. IOP Conf. Ser.: Earth Environ. Sci. 2019; 248, 012062.

[4] W Douven. Human pressure on marine ecosystems in the Teluk Banten coastal zone: Present situation and future prospects. Teluk Research Program Report Series 3, IHE, Delft, Netherlands, 1999.

[5] C Satrya, M Yusuf, M Shidqi, B Subhan, D Arafat and F. Aggraeni. Seagrass diversity in Banten Bay, the province of Banten. Jurnal Teknologi Perikanan dan Kelautan 2013; 3, 29-34.

[6] UJ Wisha, S Husrin and J Prihantono. Hydrodynamics Banten Bay during transitional seasons (August-September). Ilmu Kelautan. 2015; 20, 101-12.

[7] K Munawir and D Yogaswara. Concentrations of PAHs (Polycyclicaromatic Hydrocarbons) pollutant in sediment of Banten Bay. Bull. Mar. Geol. 2017; 32, 61-6.

[8] A Bayhaqi, UJ Wisha and D Surinati. Modeling tidal current of Banten Bay during transitional monsoons 2015-2016. J. Segara 2018; 14, 95-105.

[9] M Mubarak. Coastline changes in the north of Bengkalis Island, Indonesia: Satellite imagery analysis and observation. J. Degrade. Min. Land Manag. 2018; 5, 1127-32.

[10] D Danial, K Jusoff, A Asmidar, H Hamsiah and CY Syah. Analysis of coastline changes using satellite image data at Tanjung Bunga Makassar, South Sulawesi. World Appl. Sci. J. 2013; 26, 3741.

[11] K Ervita and MA Marfai. Shoreline change analysis in Demak, Indonesia. J. Environ. Protect. 2017; 8, 940-55.

[12] P Aryastana, IM Ardantha and KW Candrayana. Coastline change analysis and erosion prediction using satellite images. Matec Web Conf. 2018; 197, 13003.

[13] PG Sanderson. The application of satellite remote sensing to coastal management in Singapore. Ambio 2001; 3, 43-8.

[14] A Chrysanti, MB Adityawan, Widyaningtyas, BP Yakti, J Nugroho, K Zain, I Haryanto, M Sulaiman, A Kurniawan and H Tanaka. Prediction of shoreline change using a numerical model: Case of the Kulon Progo Coast, Central Java. Matec Web Conf. 2019; 270, 04023.

[15] SK McFeeters. The use of normalized difference water index (NDWI) in the delineation of open water features. Int. J. Rem. Sens. 1996; 17, 1425-32.

[16] DH Zhao, HW Shen, GQ Tabios, JS Lai, WY Tan. Finite-volume two-dimensional unsteady-flow model for river basins. J. Hydraulic Eng.1994;120, 863.

[17] NT Ouellette, $\mathrm{H} \mathrm{Xu}$ and E Bodenschatz.A quantitative study of three-dimensional Lagrangian particle tracking algorithms. Exp. Fluid 2006; 40, 301-13. 
[18] CW Gardiner. Handbook of stochastic methods for physics, chemistry and the natural sciences. Appl. Optic 1986; 25, 3145.

[19] J Wilkie. Numerical methods for stochastic differential equations. Phys. Rev. E 2004; 70, 017701.

[20] YI Kusuma, SM Simanjuntak, WS Pranowo, N Riyadi. Modeling hydrodynamic of barrier wall and sedimentation in Koarmatim harbor pool Surabaya. Jurnal Chart Datum 2018; 4, 28-42.

[21] B Triatmodjo. Teknik Pantai. Vol II. Beta Offset, Yogyakarta, Indonesia, 1999.

[22] IG Hendrawan, K Asai. Study of suspended sediment distribution using numerical model and satellite data in Benoa Bay-Bali, Indonesia. IJReSES. 2008; 5, 84-91.

[23] Coastal Engineering Research Center (US). Shore Protection Manual. Vol IV. U.S. Government Printing Office, Washington, D.C., 1984.

[24] INS Kesumajaya, Sutikno, A Poniman and A Wijanarto. Coastal morphodynamic study using multi temporal data in Banten Bay, Indonesia. Jurnal Ilmiah Geomatika 2009; 15, 64-79.

[25] S Husrin, J Prihantono and $\mathrm{H}$ Sofyan. Impacts of marine and sand mining activities to the community of Lontar village, Serang-Banten. Bull. Mar. Geol. 2014; 29, 81-90.

[26] J Prihantono, IA Fajrianto and YN Kurniadi. Hydrodynamics and sediment transport modelling around Tanjung Pontang coastal waters, district of Serang-Banten. Jurnal Kelautan Nasional 2018; 13, 75-88.

[27] P Hoekstra, H Lindeboom, R Bak, GVD Bergh, DA Tiwi, W Douven, J Heun, T Hobma, T Hoitink, W Kiswara, E Meesters, Y Noor, N Sukmantalya, S Nuraini and TV Weeing. Teluk Banten research programme: An integrated coastal zone management study (1995-2001). In: Proceedings of Workshop Scientific Programme Indonesia-Netherlands, 2003.

[28] AC Bayu, SR Pudjaprasetya, UJ Wisha and S Husrin. Numerical simulation of tidal bore bono at Kampar River. J. Appl. Fluid Mech. 2019; 12, 311-8.

[29] GA Rahmawan, S Husrin and J Prihantono. Bathymetry changes analysis in Serang district waters caused by seabed sand exploitation. Jurnal Ilmu dan Teknologi Kelautan Tropis 2017; 9, 45-55.

[30] A Rustam, NS Adi, E Mustikasari, TL Kepel and MA Kusumaningtyas.Sediment distribution characteristics and sedimentation rate in Banten Bay. Jurnal Segara 2018; 14, 137-44.

[31] P Hawati, DN Sugianto, S Anggoro, A Wirasatriya and S Widada. Waves induce sediment transport at coastal region of Timbulsloko Demak. IOP Conf. Ser.: Earth Environ. Sci. 2017; 55, 012048.

[32] C Wang, C Shen, PF Wang, J Qian, J Hou and JJ Liu. Modeling of sediment and heavy metal transport in Taihu Lake, China. J. Hydrodyn. 2013; 25, 379-87.

[33] Z Chen, C Hu, FE Muller-Karger and ME Luther. Short-term variability of suspended sediment and phytoplankton in Tampa Bay, Florida: Observations from a coastal oceanographic tower and ocean color satellites. Estuar. Coast. Shelf Sci. 2010; 89, 62-72. 